\section{A Closed-capture Irrigation Effluent System For Monitoring Large Container Leachate}

\author{
Edward W. Bush, \\ Ann L. Gray, ${ }^{2}$ \\ Paul W. Wilson, ${ }^{3}$ and \\ Robert I. Edling ${ }^{4}$
}

AdDITIONAL INDEX WORDS. container effluent, irrigation volume, irrigation efficiency

Summary. Irrigation management is essential in producing quality woody ornamentals and minimizing off-site runoff. The closed-capture effluent device provided an inexpensive method of monitoring effluent in large containers throughout the year with minimal effort. Daily irrigation requirements for 'Little Gem' southern magnolia (Magnolia grandifolia) were established throughout an entire growing season. The maximum daily water requirement was approximately 3 gal (11.4 L).

$\mathrm{L}$ imited research has been conducted on the relationship between irrigation volume and fertilizer leaching (Beeson and Knox, 1991; Niemiera and Leda, 1993). Fare et al. (1994) designed a water collection module to capture overhead irrigation runoff from 1 -gal (3.8-L) nursery container production. Fain et al. (1999) determined that using microirrigation provided an efficient method for irrigating large pot-in-pot container trees. Improper management of micro-irrigation can cause accumula-

Department of Horticulture, Louisiana State University Agricultural Center, 137 J.C. Miller Hall, Baton Rouge, LA 70803

Approved for publication by the director of the Louisiana Agricultural Experiment Station as Manuscript num ber 00-28-0237. This research was supported by funds from State and matching funds allocated to the Louisiana State University Agricultural Center.

${ }^{1}$ Associate professor; to whom reprint requests should be addressed.

${ }^{2}$ Research associate.

${ }^{3}$ Professor.

${ }^{4}$ Associate professor, Biological and Agricultural Engineering, Louisiana State University Agricultural Center, 119A E. B. Doran Hall, Baton Rouge, LA 70803
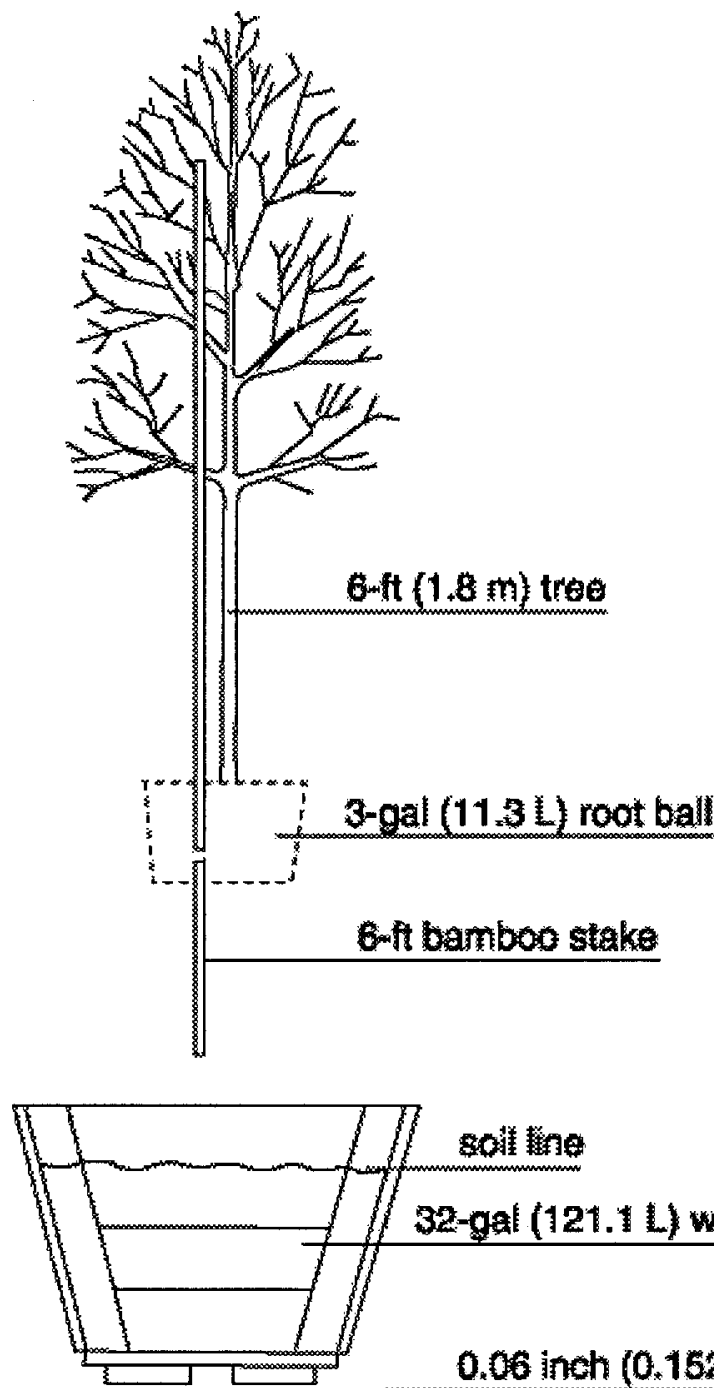

solut a

32-gal (121.1L) wooden tres box

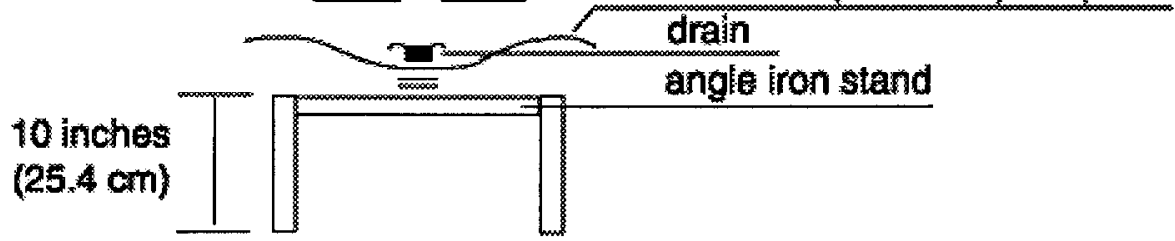

6-gat (22.7 L) water container

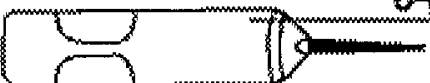

Fig. 1. Schematic representation of effluent collection apparatus.

tion of salts in the growing medium (Mason, 1994). More research is needed to determine irrigation requirements for large $[\geq 15$-gal (56.8-L)] container production optimizing plant growth and decreasing nutrient runoff. One method of irrigation management for nursery crops is monitoring the percentage effluent passing through container substrate for each irrigation event (Yeager et al., 1997). Measuring percent effluent can be used as a method of increasing irrigation precision and reducing fertilizer runoff. Considering the potential high soil bulk density and daily water evaporation potential a sturdy effluent collection device is needed.

Therefore, a closed-capture system was designed, constructed, and tested for the purpose of determining irrigation volume and quality to monitor large nursery container effluent.

\section{Materials and methods}

Apparatus. A simple closed-capture irrigation effluent system was constructed from components available at most building supply stores. The closed capture system was constructed of 1 inch $(2.5-\mathrm{cm})$ metal angle iron which 


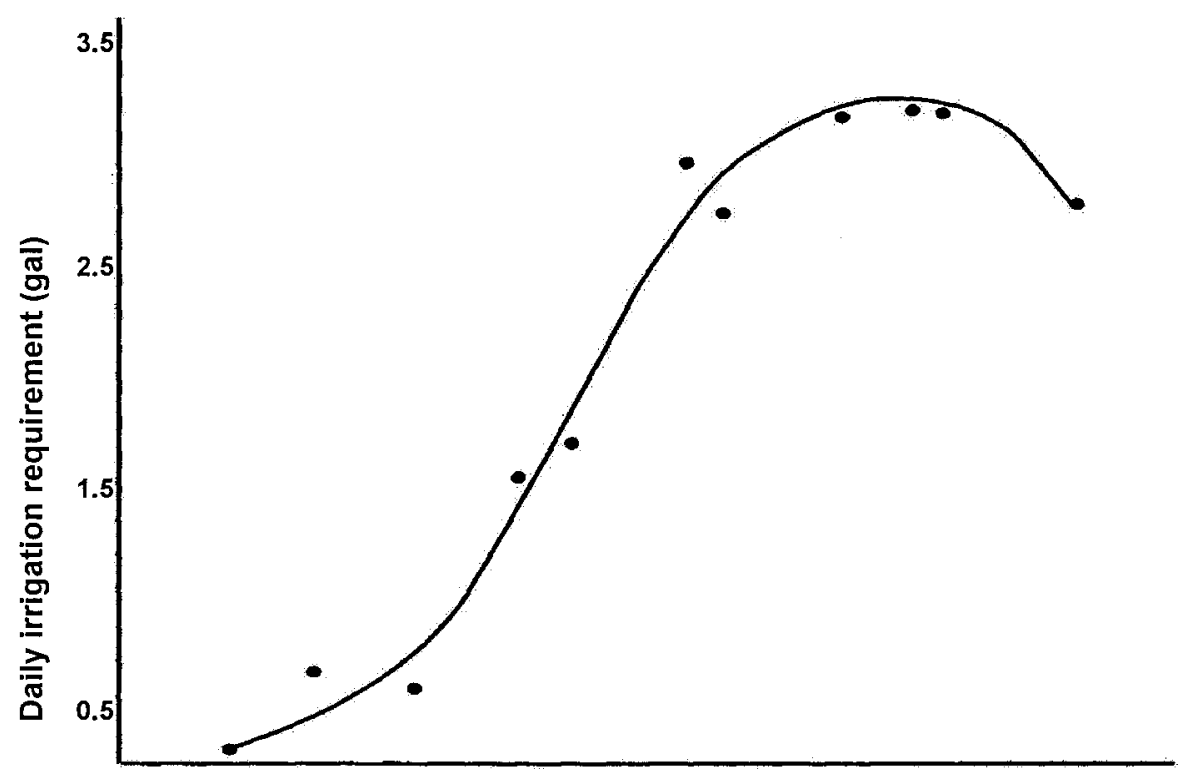

Jan. Feb. Mar. Apr. May June July Aug. Sept. Oct.

Month

Fig. 2. Daily irrigation requirement of 'Little Gem' magnolia using a closedcapture apparatus; 1 gal $=3.76 \mathrm{~L}$.

was 0.25 -inch $(0.635-\mathrm{cm})$ thick, welded to compose an $18 \times 18$-inch $(45.7-\mathrm{cm})$ square metal frame supported by four 10 -inch $(25.4-\mathrm{cm})$ legs welded to the corners of the frame. A $24 \times 24$-inch $(61-\mathrm{cm})$ square piece of butyl rubber was draped over the top surface of the metal frame with a small sink drain fixture tapped into the center. A 32-gal (121.1-L) wooden tree box was placed on top of the butyl rubbercovered frame. A6gal (22.7-L) capacity igloo water jug with a 4 -inch $(10.2-\mathrm{cm})$ circumference hole drilled near the top side of the container was placed beneath the tree stand. The drain assembly rubber gasket was seated onto the corresponding drilled 4 -inch hole drilled into the container to reduce water evaporation. The drain was positioned in the center of the metal frame. The closed-capture system allowed 6 gal of effluent to be collected.

IrRigation data. Eight 3-gal container-grown 'Little Gem' southern magnolia (Magnolia grandifolia) were planted into 32-gal tree boxes filled with a 3 pine bark : 1 sand : 1 peat (by volume) medium amended with nitrogen $(\mathrm{N})$ at $2 \mathrm{lb} / \operatorname{yard}^{3}\left(1.2 \mathrm{~kg} \cdot \mathrm{m}^{-3}\right)$, Nutricote $17 \mathrm{~N}-0.3 \mathrm{P}-6.6 \mathrm{~K}$ fertilizer (Chissu-Asahi fertilizer Co., LTD. Tokyo, Japan $)$ and $8 \mathrm{lb} /$ yard $^{3}\left(4.7 \mathrm{~kg} \cdot \mathrm{m}^{-3}\right)$ dolomitic lime. Tree boxes were then placed onto the collection stands and effluent volume, $\mathrm{pH}$, and electrical conductivity (EC) was monitored. Effluent percentage was maintained at approximately $20 \%$ of water applied to the surface of the medium substrate using eight in-line emitters regulated at 20 $\mathrm{lb} /$ inch $^{2}\left(2.7 \mathrm{~kg} \cdot \mathrm{cm}^{-2}\right)$ having a flow rate of $0.5 \mathrm{gal} / \mathrm{h}\left(1.9 \mathrm{~L} \cdot \mathrm{h}^{-1}\right)$ per emitter (Drip-In Irrigation Co., Fresno, Calif.).

\section{Results and discussion}

The collection stand provided an inexpensive method to monitor large container irrigation effluent quantity and quality (Fig. 1). The stand provided adequate support for the weight of the tree, container, and medium. The volume of irrigation required to achieve $20 \%$ leaching for 'Little Gem' magnolia ranged from $0.5 \mathrm{gal} / \mathrm{d}\left(1.9 \mathrm{~L} \cdot \mathrm{d}^{-1}\right)$ in January and continued to increase throughout the summer months before declining in September. The greatest irrigation volume was slightly less than $3.25 \mathrm{gal}(12.3 \mathrm{~L})$ daily occurring during August (Fig. 2). Temperatures peaked during August increasing irrigation re-

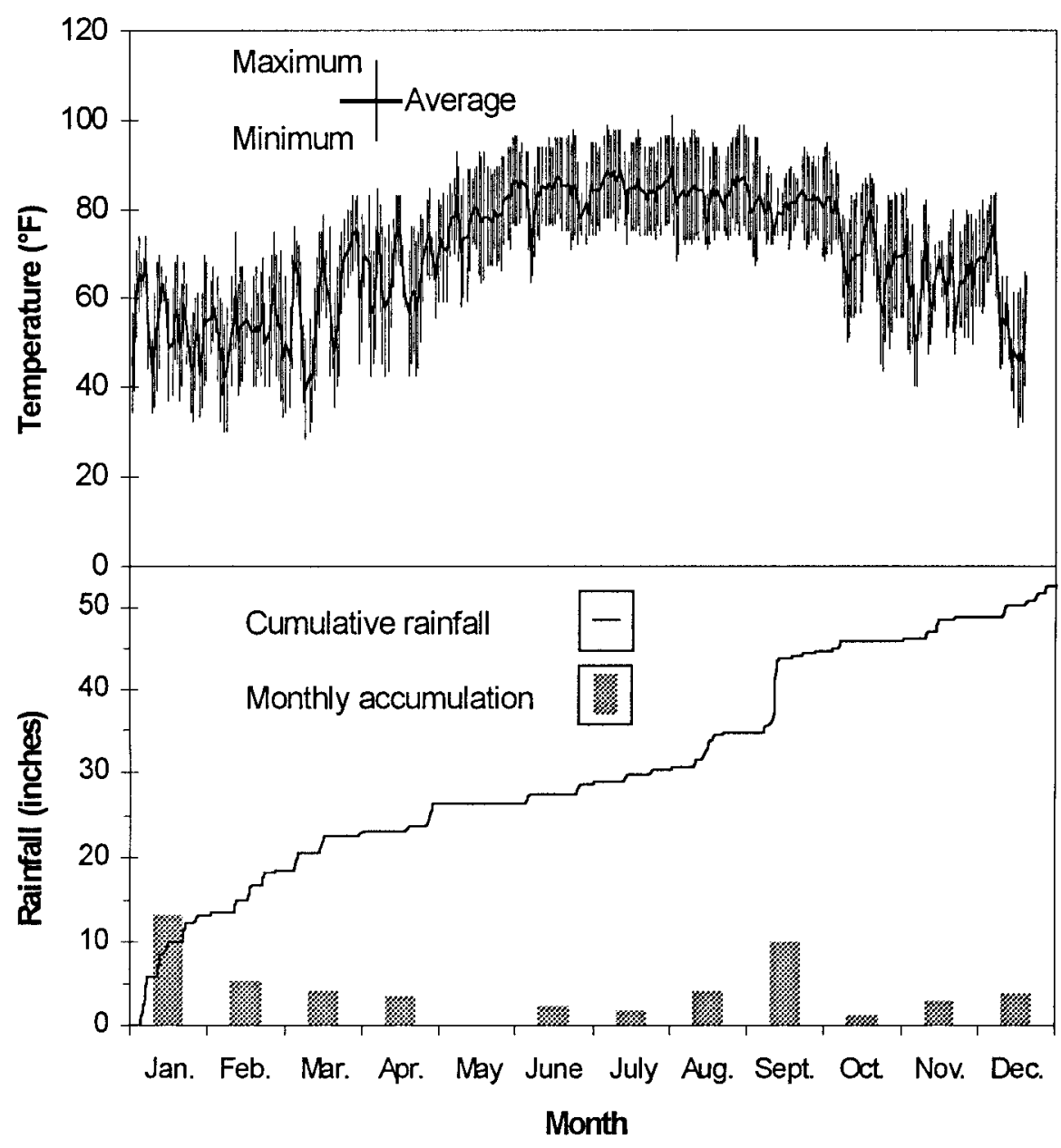

Fig. 3. Maximum and minimum temperatures and cumulative rainfall measured in Baton Rouge, La., in 1998; ${ }^{\circ} \mathrm{C}=5 / 9\left({ }^{\circ} \mathrm{F}-32\right), 1$ inch $=2.54 \mathrm{~cm}$. 


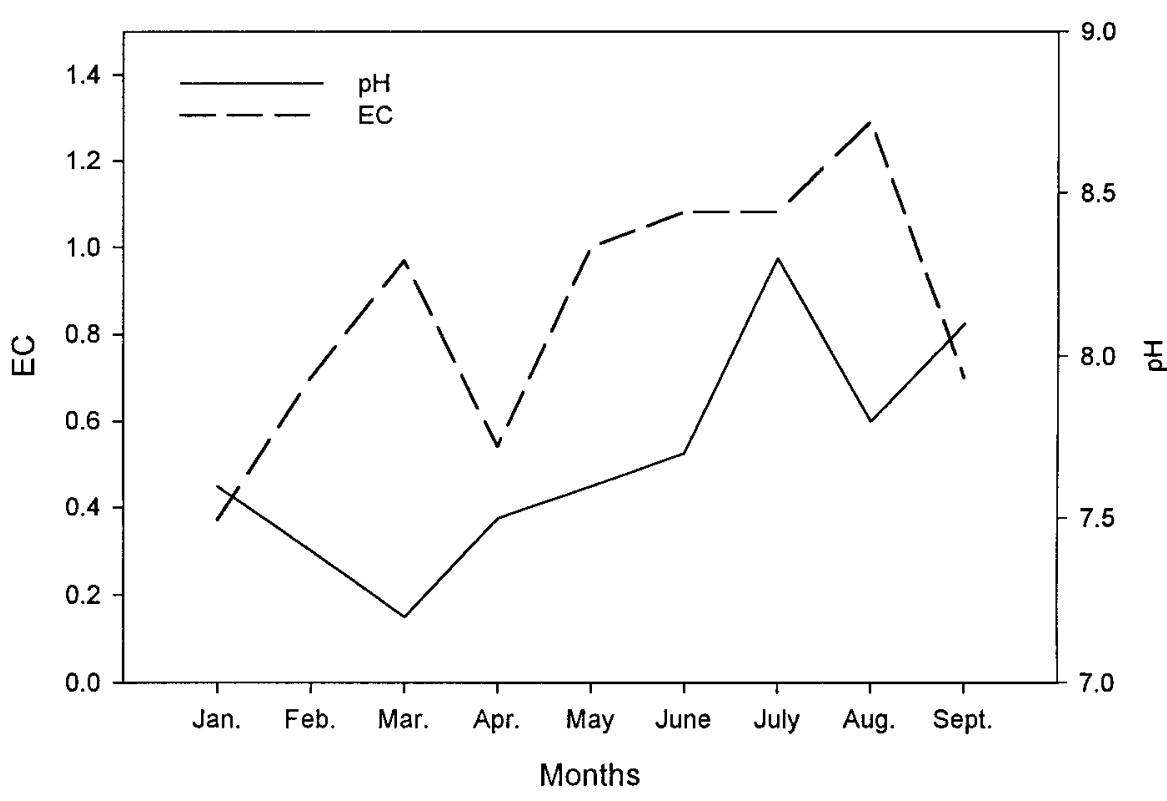

Fig. 4. Medium leachate analysis for $\mathrm{pH}$ and electrical conductivity (EC) in 1998.

quirements. There was a sharp decrease in irrigation required from August to October with decreasing temperatures.

Yeager (1998) reported that monitoring both water use and discharge is essential in identifying water requirements and accumulation of soluble salts during timesofinadequaterainfall. Effluentanalysis during the month of August in this study determinednutrients (N, Phosphorus, Potassium, Calcium, Magnesium) were at acceptable levels and pH (7.8) at slightly higher than recommended (Fig. 3 and 4). Below normal rainfall high temperatures, and water evaporation may have been responsible for increased leachate electro conductivity (EC) and pH measurements (Fig. 4).Additional irrigation was required to leach accumulated salts.

The closed capture system could be used as an objective nursery irrigation management tool providing data to make informed decisions. Yearly accumulated data could eventually be transformed into an irrigation model for each species, media, and climate. Previous research has shown that effluent based irrigation could reduce fertilizer and irrigation requirements (Davis, et al., 2001). Monthly monitoring reports could provide adequate data for managing irrigation; as well as, monitoring nutrient availability and leaching.

\section{Literature cited}

Beeson, Jr., R.C. and G.W. Knox. 1991. Analysis of efficiency of overhead irrigation in container production. HortScience 26(7):848-850.

Davis, M.K., E.W. Bush, and J.S. Kuehny. 2001. The effects of leaching fraction and fertilizer concentration on Euphorbia pulcherrima 'Freedom Red'. Proc. S. Nursery Assn. Res. Conf. 46:140-143.

Fain, D.C., Tilt, K.M., C.H. Gilliam, H.G. Ponder, and J. L. Sibley. 1999. Cyclic irrigation improves irrigation application efficiency and growth of sawtooth oak. J. Arboricult. 25:200204.

Fare, D.C., C.H. Gilliam, G.J. Keever, and J.W. Olive. 1994. Irrigation reduces container leachate nitrate-nitrogen concentration. HortScience 29(12):1514-1517.

Mason, J. 1994. Nursery management. Kangaroo Press, Kenthurst, Australia.

Niemiera, A.X. and C.E. Leda. 1993. Nitrogen leaching from osmocote-fertilized pine bark at leaching fractions of 0 to 0.4 . J. Environ. Hort. 11:75-77.

Yeager, T.H., C.H. Gilliam, T.E. Bilderback, D.C. Fare, A.X. Niemiera, and K.M. Tilt. 1997. Best management practices guide for producing container-grown plants. S. Nursery Assn., Marietta, Ga.

Yeager, T.H. 1998. Water sample collection procedures for container nurseries. Proc. S. Nursery Assn. Res. Conf. 43:526-528.

\section{Control of Powdery Mildew on Leaves and Stems of Gooseberry}

\author{
Deric D. Picton ${ }^{1}$ and \\ Kim E. Hummer ${ }^{2}$
}

Additional INDEX WORDS. Ribes $u$ vacrispa, Ribes grossularia, Sphaerotheca mors-uvae, efficacy, mineral oil, biological control, Trichoderma

Summary. Powdery mildew (Sphaerotheca mors-uvae) severely infects young leaves and stems of gooseberry (Ribes uva-crispa) throughout the world. Environmentally friendly control measures are being sought as alternatives to sulfur or demethylation inhibiting fungicides. This study examined the effect of a mineral oil spray, the biological control agent Trichoderma barzianum Rifai strain T-22 (Trichoderma), a combination mineral oil + Tricoderma, and the chemical fungicide thiophanate, on powdery mildew severity in 'Industry,' a susceptible gooseberry. Mineral oil at $8 \mathrm{~mL} \cdot \mathrm{L}^{-1}$ (1.0 $\mathrm{fl} \mathrm{oz} / \mathrm{gal})$, Tricoderma at $4 \mathrm{~g} \cdot \mathrm{L}^{-1}$ $(0.5 \mathrm{oz} / \mathrm{gal})$ and thiophanate at 1.45 $\mathrm{mL} \cdot \mathrm{L}^{-1}(0.186 \mathrm{fl} \mathrm{oz} / \mathrm{gal})$, and mineral oil + Tricoderma mix was applied to plants until runoff at 2 -week intervals from February 2002 through April 2002 , on potted 'Industry' plants growing in a greenhouse in U. S. Department of Agriculture, Agricultural Research Service, National Clonal Germplasm Repository (NCGR), Corvallis, Ore. The percent of infected leaves per plant were calculated and the percent of infected stem surface areas were visually rated in mid-April. The fungicide, mineral oil, and mineral oil + Tricoderma treatment applications significantly reduced powdery mildew severity in

The use of trade names does not imply endorsement of the products named nor criticism of similar ones not named. We acknowledge the Northwest Center for Small Fruits Research and CRIS 5358-21000-029$00 \mathrm{D}$ for providing funding support for this project.

${ }^{1}$ Graduate research assistant, Department of Horticulture, Oregon State University, Corvallis, Oregon, 97330. Present address: BARC-West, Floral and Nursery Plants Research Unit, 10300 Baltimore, Ave. Bldg 010A Beltsville, MD, 20705-2350

${ }^{2}$ Research leader, USDA ARS NCGR, 33447 Peoria Road, Corvallis, Oregon 97333-2521; to whom corre spondence should be addressed; e-mail khummer@arsgrin.gov. 
both leaves and stems as compared with those of the unsprayed plants. The stem powdery mildew reduction levels of the mineral oil or a combination of mineral oil + Trichoderma treatments, were not statistically different than that of thiophanate, which is reported as commercially acceptable. We recommend mineral oil spray, or mineral oil + Tricoderma, as alternatives to fungicide control of powdery mildew on leaves and stems of young gooseberry plants.

$\mathrm{P}$ owdery mildew is a spring and summer disease of gooseberries in Asia, Europe, North America, Australia, and New Zealand (Diekmann et al., 1994). This disease can be severe in the rainy, mild climate of the Pacific northwestern United States. The fungus appears as a white powdery growth on the young leaf and stem surfaces and can cause stunting and a reduction in marketable fruit (Pscheit, 2002).

Control recommendations for powdery mildew in fruit crops include inorganic sulfur in dust or wettable formulations, and demethylation-inhibitor fungicides (Dell etal., 1998; Pscheidt, 2002). A biological control containing the fungal hyperparasite Ampelomyces quisqualis in a mineral-oil-based surfactant is a mildew preventative (Pscheidt, 2002). Trichoderma harzianum isolates can control foliar and soilborne fungi including Botrytis cinerea, Pseudoperonospora cubensis, Sclerotinia sclerotiorum and Sphaerotheca spp. (Elad, 2000; Scheuerell and Mahaffee, 2000). The organism has multiple modes of action that inhibit or kill the pathogen (Elad, 2000). These organisms may not provide commercially accepted control with present formulations.

Mineral oil has proven effective in controlling powdery mildew on grapes (Vitisvinifera) (Dell et al., 1998), roses (Rosa spp.)(McWhorter, 1927) and hops (Humulus lupulus) (Pscheidt, 2002). Oil is effective in low concentrations, has little or no toxicity to animals, and is relatively inexpensive (Dell et al., 1998). Mineral oil was effective in reducing mildew infection in black currants (Ribes nigrum) (Hummer and Picton, 2001) and in reducing white pine blister rust (caused by Cronartium ribicola) on Ribes (Picton and Hummer, 2003). Calpouzos (1966) mentions two disadvantages: that oil may not be effective against some of plant diseases, and that it may cause phyto- toxicity. The object of this study was to determine if mineral oil, Tricoderma, or a combination of mineral oil + Tricoderma, could reduce powdery mildew on leaves and stems of susceptible gooseberries in contrast with control from the recommended commercial fungicide, thiophanate.

\section{Materials and methods}

'Industry' was chosen for this study based on preliminary observations of naturally occurring powdery mildew in the cultivated gooseberries at NCGRCorvallis. 'Industry' is highly susceptible to powdery mildew (Brennan, 1996). In January 2002, 'Industry' plants were placed in the greenhouse in Corvallis, Ore., in a completely randomized design with four replicates of five treatments with a total of 20 plants. This study was conducted on 2-year-old plants that had not reached full fruiting capacity.

The treatments were applied at 2week intervals from February 2002 through April 2002. They included an unsprayed control, mineral oil (JMS Stylet Oil; JMS Flowers Farms, Inc., Vero Beach, Fla.), Tricoderma (Plantshield; Bioworks Inc., Geneva, N.Y.), thiophanate (Cleary 3336; W.A.
Cleary Chem. Co., Summerset, N.J.), and a combination of mineral oil + Tricoderma. JMS Stylet-Oil, a highly refined paraffinic mineral oil with an unsulfonated residue of $99.1 \%$, was sprayed on treated leaves until runoff at $8 \mathrm{~mL} \cdot \mathrm{L}^{-1}$. PlantShield, a biologically active formulation of Trichoderma barzianum strain T-22 in a clay substrate, was applied at a rate of $4 \mathrm{~g} \cdot \mathrm{L}^{-1}$. Thiophanate, the recommended chemical control of mildew on gooseberries (Pscheit, 2002), was applied at 1.45 $\mathrm{g} \cdot \mathrm{L}^{-1}$. The mineral oil + Tricoderma treatment was applied mixed at the same rates as above. All sprays were applied using a handheld 1.51-L (0.4-gal) sprayer.

In mid-April, the powdery mildew infection of leaves and stems on current year's growth was visually assessed by observing the undersides of the leaves. Infected and total leaves of the plant were counted, and the percent of infected leaves per plant was calculated. Young, green stems were also rated for mildew damage and a percent infection rating was given per plant. The leaf and stem surface area covered by fungal infection was visually rated by estimating the percent of the leaf surface showing mildew damage on a whole plant

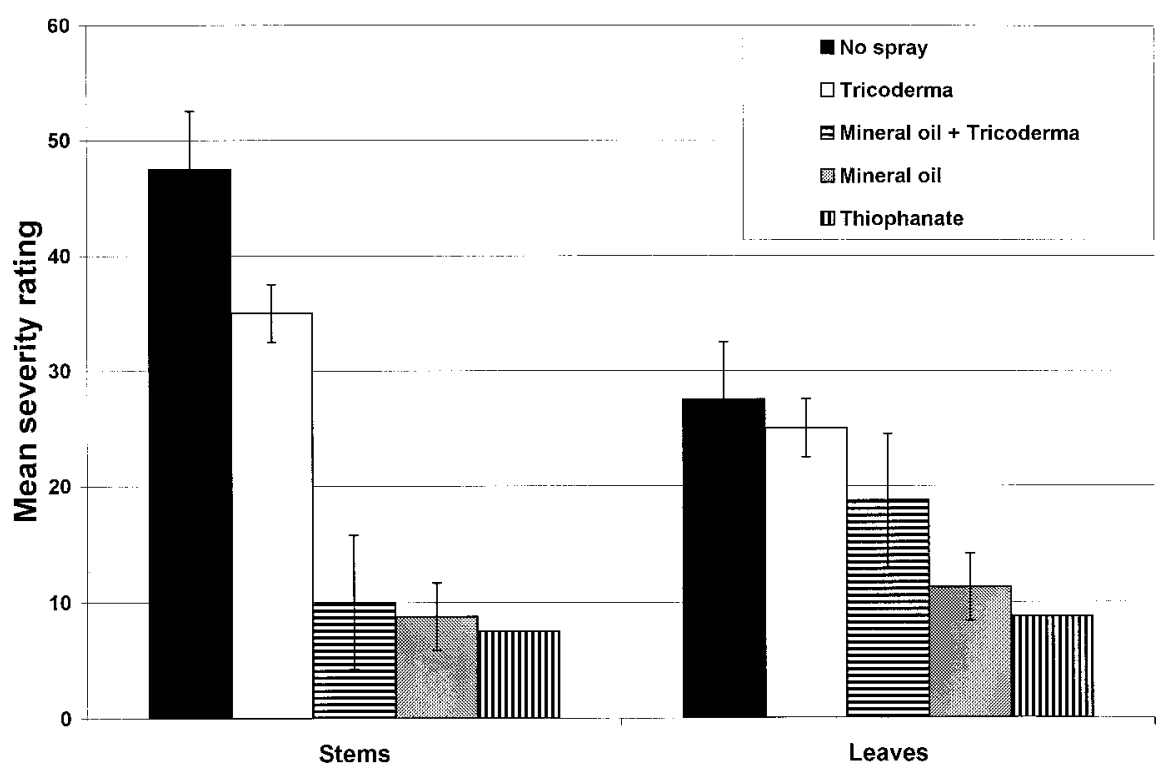

Fig. 1. Mean powdery mildew severity rating for leaves (percent infected leaves per plant) and stems (estimated percent area covered by infection), $n=4$, for five treatments on 'Industry'gooseberry: 1) no spray, 2) Trichoderma barzianum strain T-22 in a clay substrate (Tricoderma) (Plantshield; Bioworks Inc., Geneva, N.Y.) at $\left.4 \mathrm{~g} \cdot \mathrm{L}^{-1}(0.5 \mathrm{oz} / \mathrm{gal}), 3\right)$ mineral oil (JMS Stylet Oil; JMS Flowers Farms, Inc., Vero Beach, Fla) at $8 \mathrm{~mL} \cdot \mathrm{L}^{-1}(1.0 \mathrm{fl} \mathrm{oz/gal})+$ Tricoderma at $\left.4 \mathrm{~g} \cdot \mathrm{L}^{-1}, 4\right)$ mineral oil at $8 \mathrm{~mL} \cdot \mathrm{L}^{-1}$, and 5 ) thiophanate (Cleary 3336; W.A. Cleary Chem. Co., Summerset, N.J.) at $1.45 \mathrm{~g} \cdot \mathrm{L}^{-1}(0.186 \mathrm{fl} \mathrm{oz} / \mathrm{gal})$ applied at 2week intervals from Feb. 2002 through Apr. 2002. Disease severity ratings were taken on 21 Apr. 2002. Standard deviation = 0 for the mean thiophanate rating. 
basis. Analyses of variance were applied to the percentages and ratings to determine significance of the treatments. Tukey's least square difference (LSD) test was applied to separate means.

\section{Results and discussion}

Analyses of variance for ratings on both leaves and stems were highly significant $(P<0.0001)$. All treatments were significantly better than the no-spray control for stem infection (Fig. 1). Thiophanate, mineral oil, or the mineral oil + Tricoderma treatments gave the best control $(P=0.05)$ for stem infection. For leaf infection, the thiophanate and the mineral oil treatments were significantly more effective at reducing powdery mildew than was Tricoderma alone or the no spray control (Fig. 1). The combination treatment was intermediate, providing significantly less control than the fungicide treatment but not significantly less than the oil treatment (Fig. 1). These results agree with previous studies for disease control using mineral oil (Hummer and Picton, 2001; Scheuerell and Mahaffee, 2000). The lack of powdery mildew control on leaves for mineral oil + Tricoderma may be due to an interaction between a component of the biological control and the oil that reduced the coating capacity of the oil on the leaf. Tricoderma alone did not significantly reduce leaf infection (Fig. 1). Unfortunately, in this treatment we observed an increased level of leaf necrosis not caused by mildew. This damage was not observed in the other treatments. The damage appeared in the same vicinity as the mildew area. We do not recommend Tricoderma alone to control powdery mildew on gooseberries.

The powdery mildew reduction of the mineral oil or the combination of mineral oil + Tricoderma treatments were not statistically different than that of the thiophanate, which is reported as commercially acceptable. We recommend the application of mineral oil or mineral oil + Tricoderma, as alternatives to fungicide in reducing powdery mildew in leaves and stems of young, greenhouse-grown gooseberry plants. Further study is needed to determine effective controls of gooseberry fruit mildew using environmentally friendly materials.

\section{Literature cited}

Brennan, R.M. 1996. Currants and gooseberries, p. 191-295. In: J. Janick and J.N. Moore (eds.). Fruit breeding. vol. 2. Wiley, New York.

Calpouzos, L. 1966. Action of oil in the control of plant disease. Ann. Rev. Phytopathol. 4:369-390.

Dell, K.J., W.D. Gubler, R. Krueger, M. Sanger, and L.J. Bettiga. 1998. The efficacy of JMS stylet-oil on grape powdery mildew and Botrytis bunch rot and effects on fermentation. Amer. J. Enol. Vitic. 49:11-16.

Diekmann, M., E.A. Frison, and T. Putter (eds.). 1994. FAO/IPGRI Technical Guidelines for the safe movement of small fruit germplasm. Food Agr. Org. United Nations, Rome/Intl. Plant Genet. Resour. Inst., Rome.

Elad Y. 2000. Biological control of foliar pathogens by means of Trichoderma harzianum and potential modes of action. Crop Protection 19:709-714.

Hummer, K.E. and D. D. Picton. 2001. Oil application reduces powdery mildew severity in black and red currants. HortTechnology 11:445-446.

McWhorter. 1927. Fungicidal value of oil sprays. Phytopathology 17:201-202.

Picton, D.D. and K.E. Hummer. 2003. Oil application reduces white pine blister rust severity in black currants. Small Fruit Rev. 2(1):43-49.

Pscheit, J.W. 2002. Gooseberry and currant-Powdery mildew. In: Online guide to plant disease control. 25 June 2002. http://plant-disease.orst.edu/ disease.cfm? RecordID $=512$.

Scheuerell S.J. and W.F. Mahaffee. 2000. Assessing aerated and non-aerated watery fermented compost and Trichoderma harzianum T-22 for control of powdery mildew (Sphaerotheca pannosa var. rosae) of Rose in the Willamette Valley, Oregon. Phytopathology. 90(6 Supp.):S69. 